STATE OF OHIO

FRANK J. LAUSCHE, Govemor

DEPARTMENT OF NATURAL RESOURCES

A. W. MALION, Director

DIVISION OF GEOLOGICAL SURVEY

JOHN H. MELVIN, ChIOA

Livin.... \$6//3

Report of Investigations No. 23

\title{
SOURCE OF SHARON CONGLOMERATE \\ OF \\ NORTHEASTERN OHIO
}

By

J. Osborn Fuller

Reprinted from

BULLETIN OF THE GEOLOGICAL SOCIETY OF AMERICA

VOL $\infty ., P P .160-170,3$ FIG8, 2 PL8.

FEBRUARY 1966 


\title{
815 Harley Drive BULLETIN OF THE GEOLOGICAL SOCIETYCO AULAMGUS 2, OHIO \\ VOL. 66, PP. 169-176, 3 FIGS. 2 PLS. \\ FEBRUARY 1955
}

SOURCE OF SHARON CONGLOMERATE OF NORTHEASTERN OHIO

BY J. OSBORN FULLER ${ }^{1}$

\begin{abstract}
Sharon conglomerate crops out in three separate areas in Ohio and in all of these the formation has similar characteristics and is the basal Pennsylvanian bed resting unconformably on Mississippian sandstone or shale. This paper is concerned chiefly with the larger area of outcrop in northeastern Ohio which lies west of the type area at Sharon, Pennsylvania. The formation is dominantly a pure $\left(96+\% \mathrm{SiO}_{2}\right)$, medium-grained, quartz sandstone (orthoquartzite) with a few pebble layers or scattered pebbles. Laterally this rock grades into a series of narrow, conglomerate belts $1000 \pm$ feet wide and 10-50 feet thick. Trend of these belts, and, in the whole formation, dip of cross-bedding, dip of the initial slope, direction of overturning of tops of cross-beds, imbricate structure, and north-south changes in sedimentary features, mechanical analyses, and chemical analyses all indicate a northern source for the clastic material of the Sharon conglomerate and also suggest a deltaic type of depositional environment. In older literature the pebbles of the Sharon are described as "vein quartz" suggesting an igneous rock source. Fossils as pebbles, and pebbles of sandstone, and conglomerate indicate rocks that were in part sedimentary. Almost no minerals are present except quartz and most of the quartz grains show secondary growth, indicating that the individual grains have been through more than one cycle of sedimentation. Although igneous rocks were doubtlessly the original source of many of the multicycle particles, the lack of pebbles of igneous rock and grains of igneous rock accessory minerals strongly suggests that the sediments of the Sharon are several cycles removed from the original source rocks. This concept is confirmed by examination of thin sections. Most pebbles show ghost granular structure and the inclusions in both pebbles and sand grains are characteristic of quart $z$ derived from a metamorphic source.

The fossils, most of which are tabulate corals, prove that at least part of the source was Middle Devonian (Onondaga-Hamilton). The writer concludes that the Sharon sediments originated in a Canadian highland composed of a mixture of sedimentary and metamorphic rocks some of which were of Middle Devonian age, and that these sediments were transported by streams of considerable competency and were ultimately deposited as a delta in a shallow basin developed on Mississippian rocks.

The characteristics of the Sharon in southern Ohio indicate a similar origin but the clastic components were apparently derived from the southeast as shown by direction of dip of cross-beds and trend of conglomerate belts.
\end{abstract}

\section{CONTENTS}

TEXT

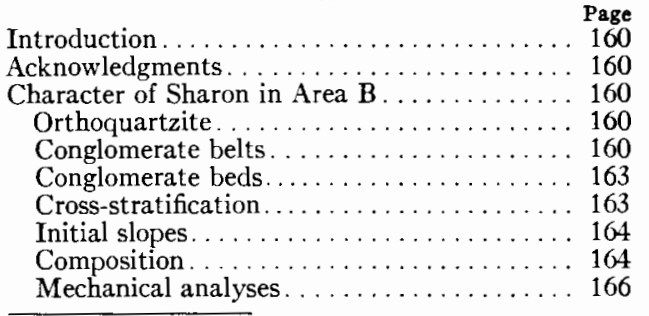

${ }_{1}$ Presented with the encouragement of the Geological Survey of Ohio.

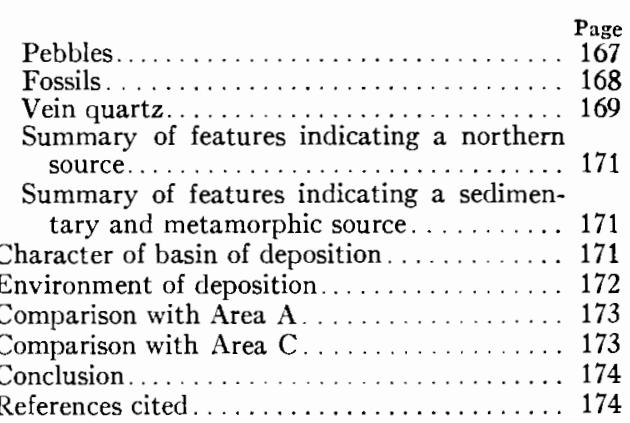




\section{ILLUSTRATIONS}

Figure Page

1. Location of the three principal areas of outcrop of Sharon conglomerate in Ohio... 161

2. Distribution of known conglomerate belts in the Sharon. . . . . . . . . . . . . . 162

3. Relationships of conglomerate to sandstone in the Sharon............. 172

\section{INTRODUCTION}

The basal Pennsylvanian Sharon conglomerate of Ohio lies disconformably on the evenbedded marine Mississippian shale and sandstone, in a relationship similar to its correlatives, the Olean of New York and the Mansfield of Indiana. In Ohio the Sharon conglomerate crops out in three separate areas (Fig. 1). Area A covers about 150 square miles in Ohio and is a continuation from the type area at Sharon, Mercer County, Pennsylvania. Area B spreads over about 2400 square miles. It is separated from Area A by the 12-mile-broad Grand River Valley which has been cut in Mississippian rocks. Area $\mathrm{C}$ covers about 450 square miles in south-central Ohio. It is separated from Areas $A$ and $B$ by an area about 100 miles along the strike in which the Sharon is lacking and the basal Pennsylvanian is a younger formation than the Sharon. This paper is chiefly concerned with Area B in which mapping has been most detailed.

\section{ACKNOWLEDGMENTS}

Work on the Sharon conglomerate was sponsored by the Geological Survey of Ohio which is interested in encouraging further exploitation of this pure silica rock already important for foundry sand, ferrosilicon and silica brick. The writer has worked on the Sharon every summer since 1941 except for an interruption during the war. He acknowledges his indebtedness to the three state geologists of Ohio under whom this work has been done: Dr. Wilber Stout, Dr. George W. White and Mr. John H. Melvin. Dr. Myron T. Sturgeon of Ohio University worked on the problem with the writer and independently during the war; he deserves credit for some of the early discoveries concerning the nature of the Sharon. The writer is also indebted to his field assistants: Dr. William M.
Plate

Facing page

1. Sedimentary features of the Sharon conglomerate ................. 162

2. Characteristics of the Sharon conglomerate.

\section{TABLE}

Table
1. Analyses of Sharon samples arranged from north to south to show systematic change...................... 165

Merrill, Dr. Charles N. Bowen, Mr. Robert E. Lehner and Mr. John J. Pedry, Drs. George W. White and J. A. Aurelé LaRocque criticised the manuscript for the writer.

\section{Character of Sharon in Area B}

\section{Orthoquartzite}

Sharon conglomerate of Area B crops out extensively in Geauga, Portage, Summit and Medina counties, and sparsely in the surrounding counties, Trumbull, Lake, Cuyahoga and Wayne (Fig. 1). In this area of about 2400 square miles the Sharon is dominantly an orthoquartzite. Average grain size is $0.25-0.5 \mathrm{~mm}$. A few scattered pebbles and pebble lenses are common and grit layers are rare. Sand grains characteristically flash light from many crystal faces of secondary quartz. Normally the Sharon is a clean, white, friable or thoquartzite with a silicon dioxide content of over 96 per cent; near the surface and along joint planes it is limonitestained and more solidly cemented. Next to limonite the chief impurities are clay and feldspar. Thickness throughout this vast sheet of orthoquartzite varies from 0 to 170 feet. Crossbedding is abundant and ripple marks are present locally.

\section{Conglomerate Belts}

Long narrow belts of conglomerate with a southerly trend lie in the orthoquartzite. They are difficult to trace because of cover and because their lateral boundaries are indistinct. The most distinctive belt extends south of Thompson, Ohio for seven miles (Fig. 2-1). Conglomerate appears $171 / 2$ miles south at Nelson Ledges (Fig. 2-2) and extends slightly east of south for 4 miles. Position and alignment suggest a possibie connection at one time between these two belts but this has not been definitely established. Two other belts are 


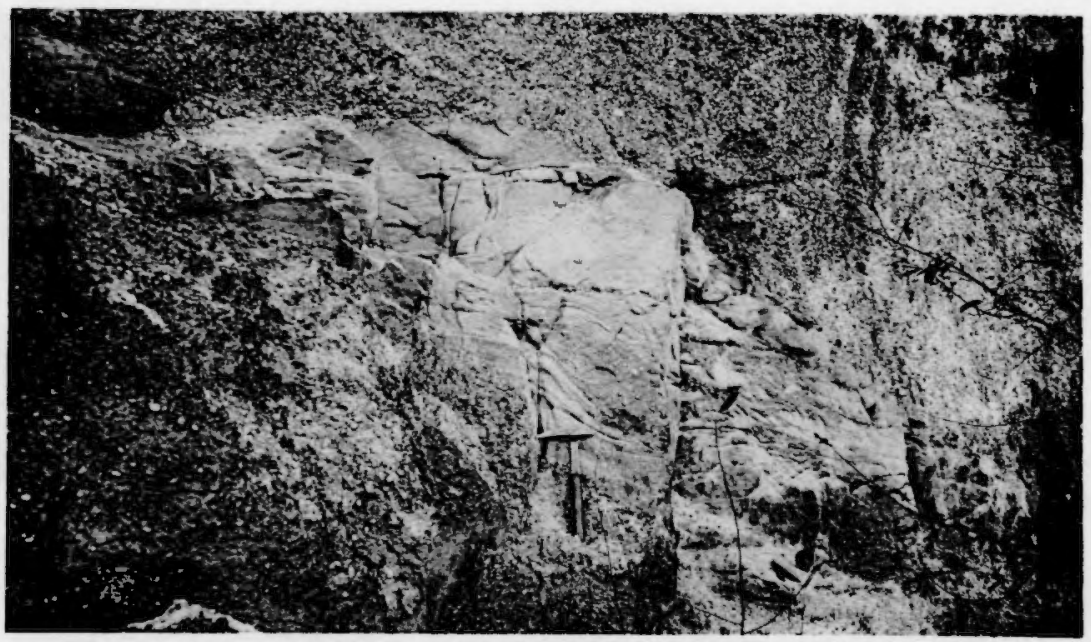

Figure 1

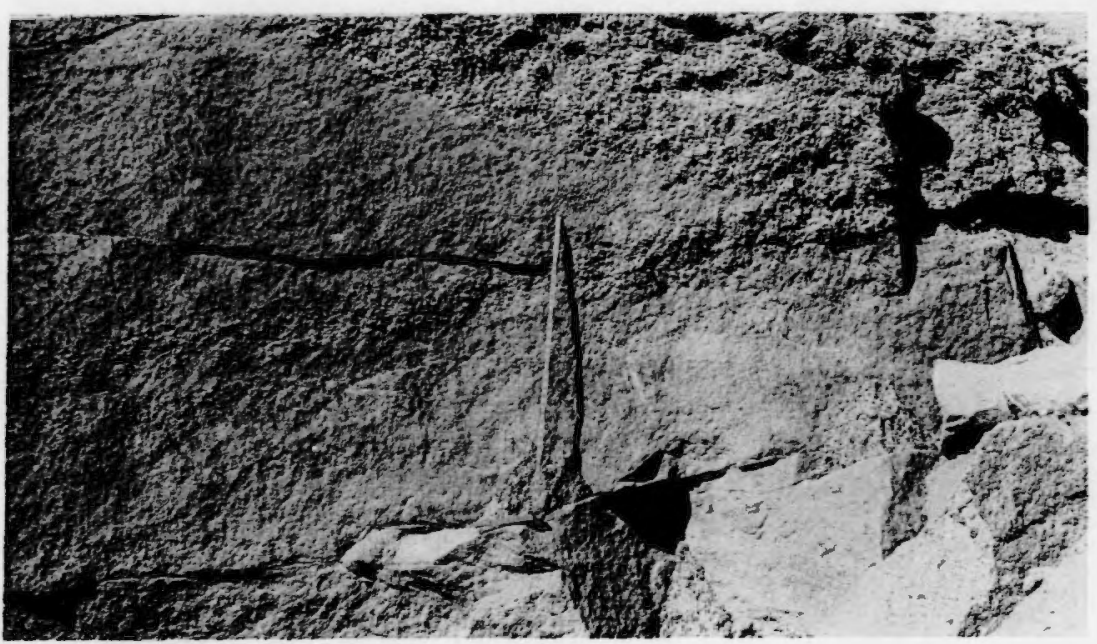

Figure 2

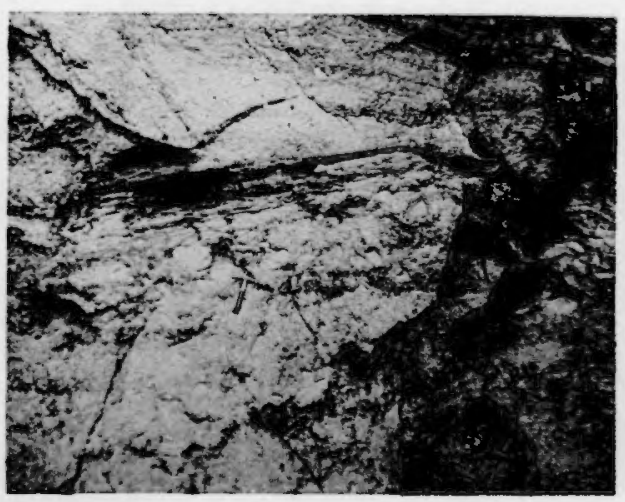

Figure 3

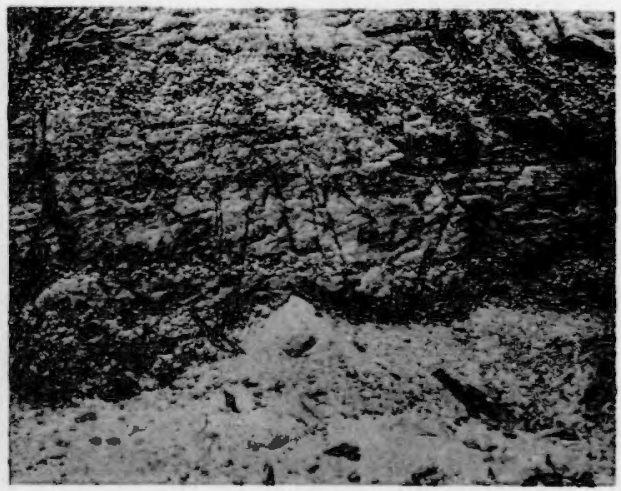

Frgure 4 

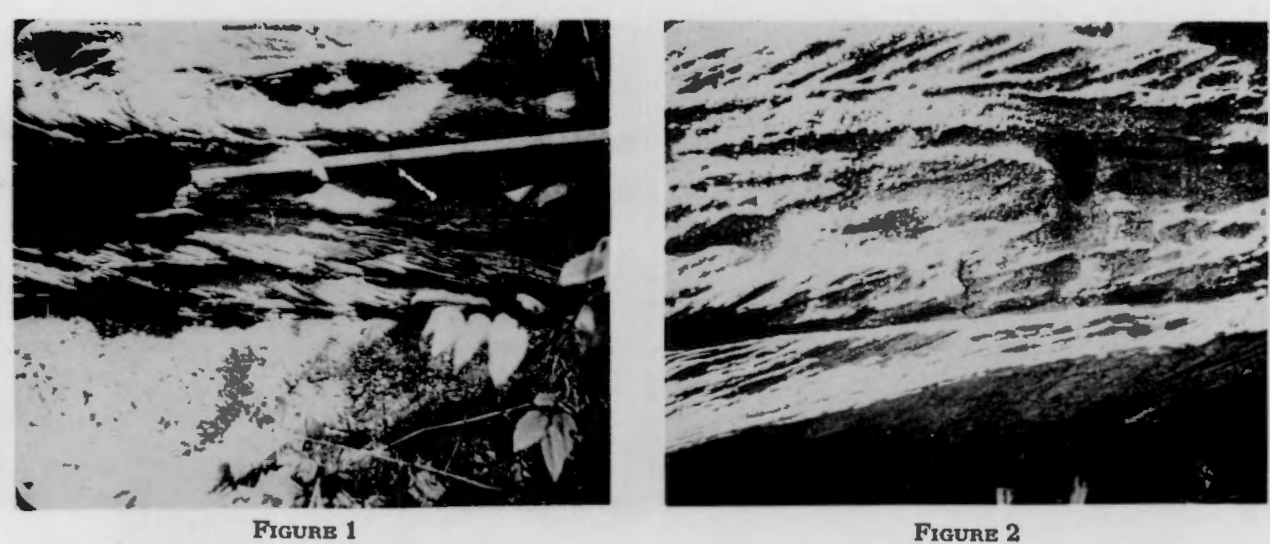

Figure 2

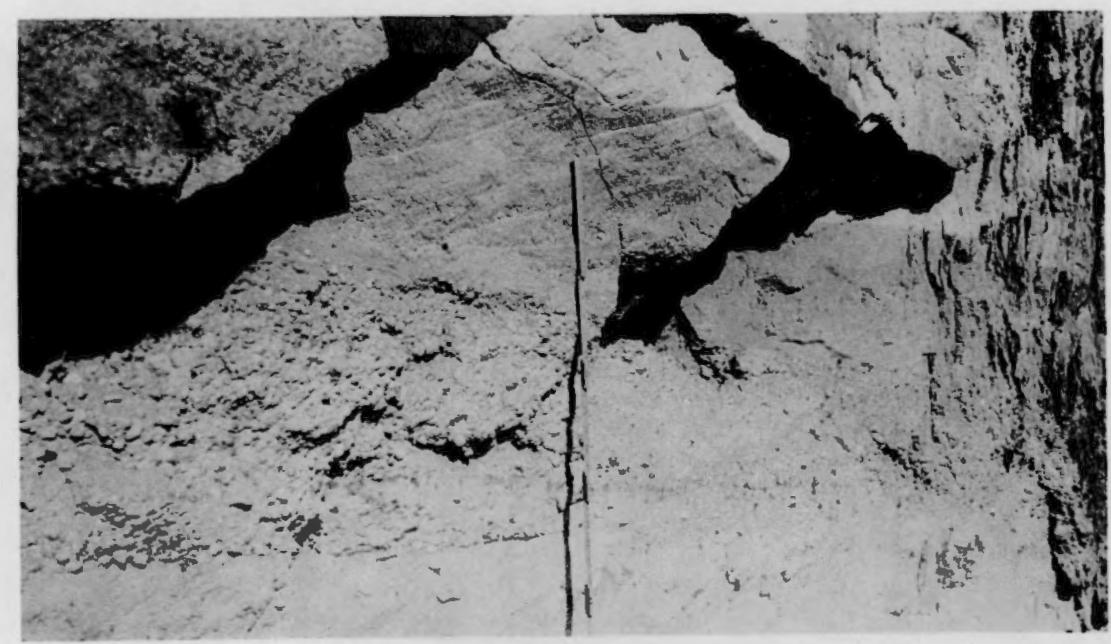

Frgure 3

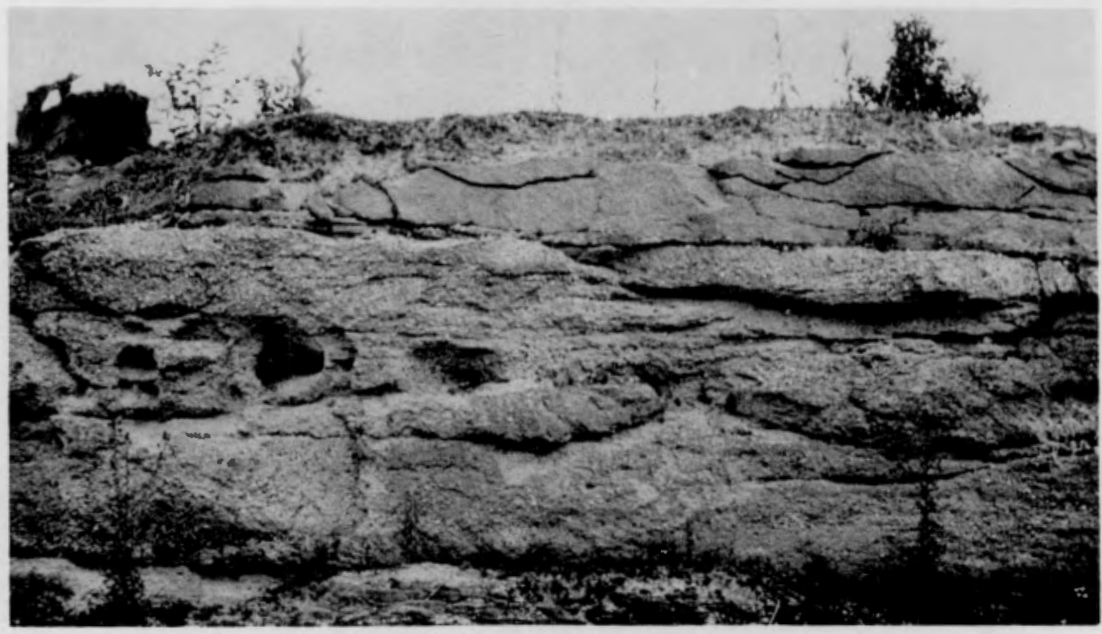

FIGURE 4

CHARACTERISTICS OF THE SHARON CONGLOMERATE 
fairly well defined, the first extending northeast for 4 miles from the Best quarry located south of Chardon (Fig. 2-3) and the second extending a conglomerate into an orthoquartzite with scattered pebbles and then into an almost pebble-free orthoquartzite. The gradational

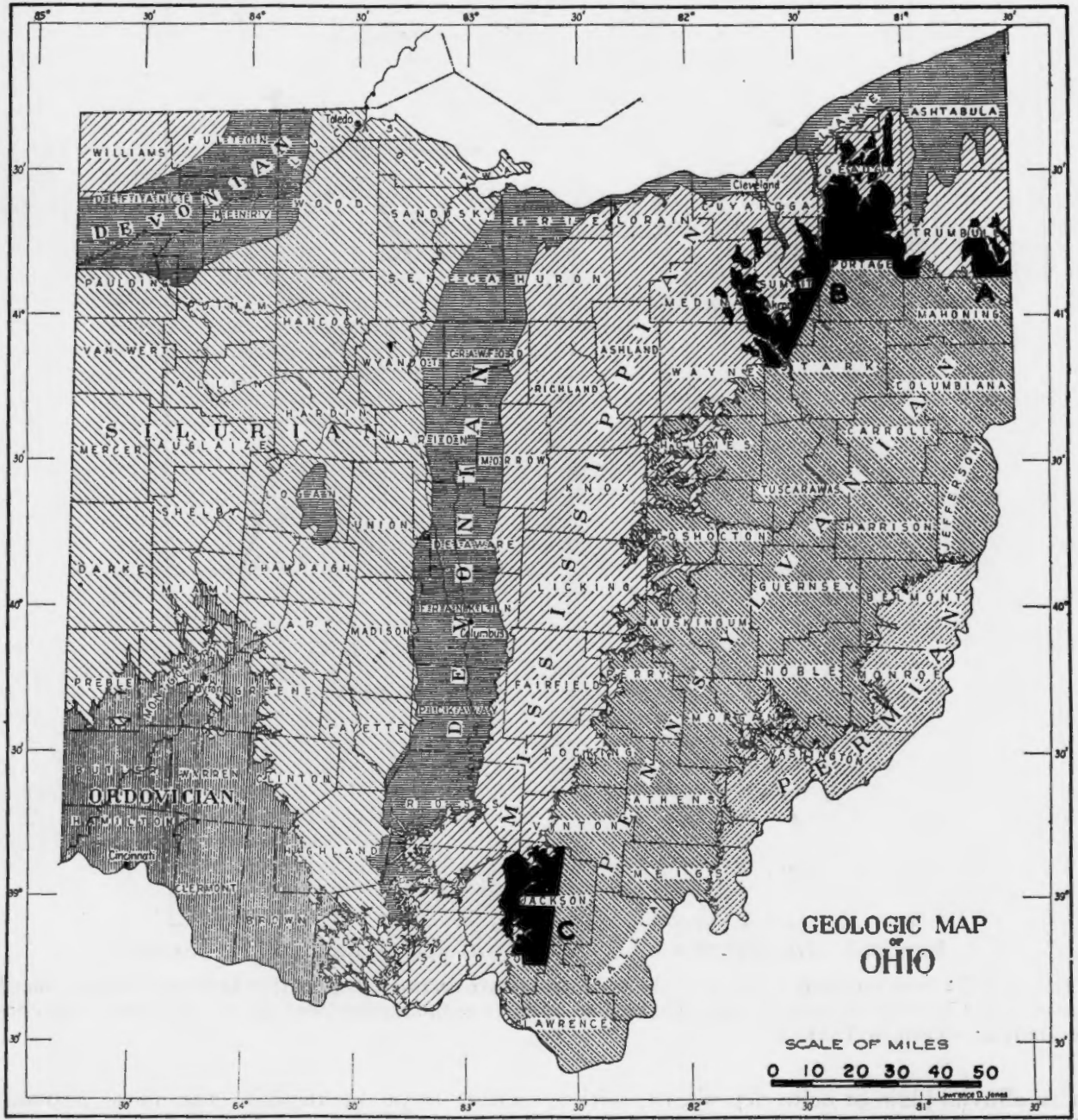

Figure 1.-Location of the Three Principal Areas of Outcrop of Sharon Conglomcrate in Ohio

Area A contiguous with the type area at Sharon, Pennsylvania; Area B the area of this report; Area C Sharon of southern Ohio

for 3 miles southwest of the Copley quarry (Fig. 2-4). Other short linear strips of conglomerate have been found (Fig. 2). The pattern and alignment of all the conglomerate belts suggest distributary channels on a deltaic or alluvial plain.

Along a conglomerate belt the material is well sorted and uniform but across a conglomerate belt in 500-1000 feet the rock grades from area frequently has lenses of orthoquartzite in the conglomerate. The long axis of some of these lenses is parallel to the bedding ( $\mathrm{Pl}$. 1, fig. 1) and in others cuts across the bedding. These lenses are believed to be remnants of sandbars and similar features, and indicate rapidly changing conditions of deposition and erosion. They are more abundant in the southern part of the area than in the northern part. 


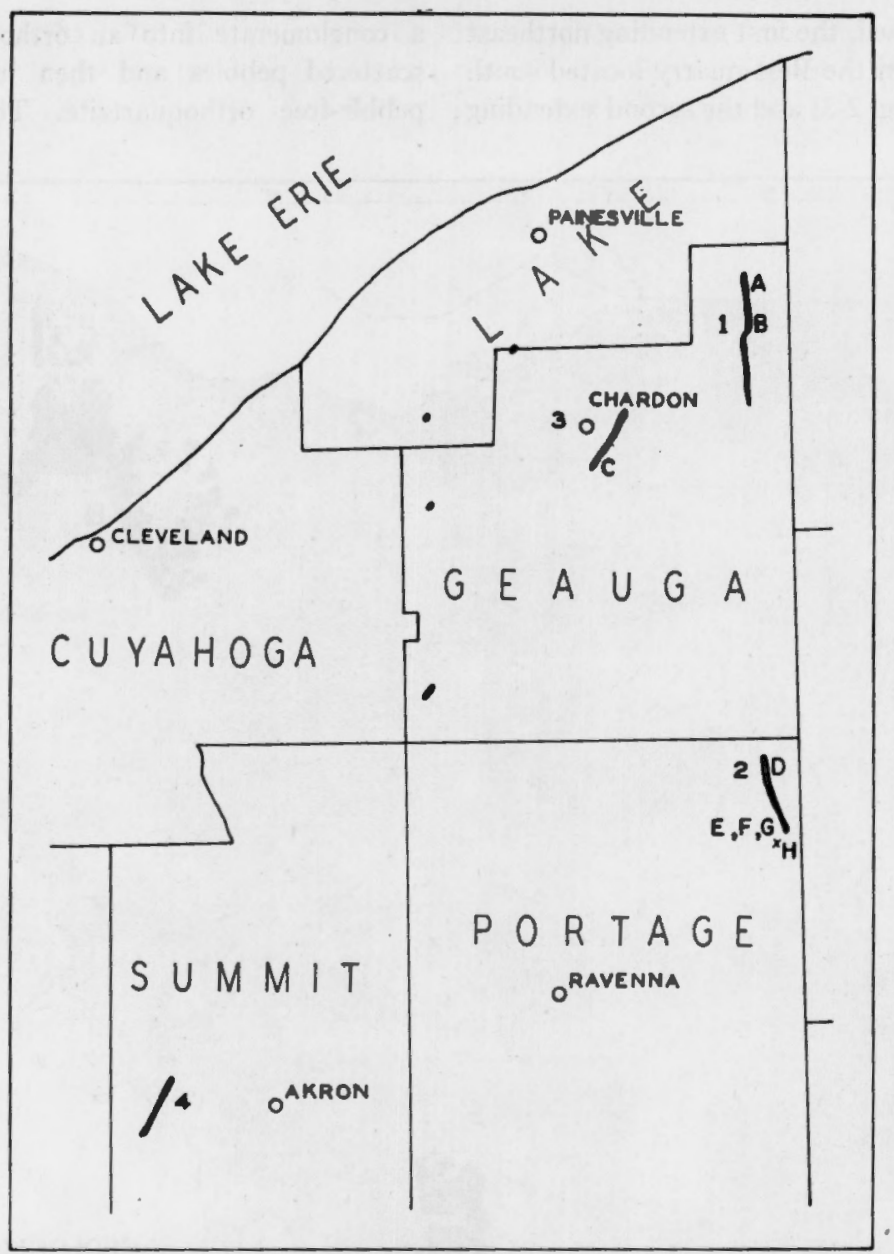

Ftgure 2.-Distribution of Known Conglomerate Belts in the Sharon

Heavy solid lines indicate position of thick conglomerate sections. Distinctive belts are: Thompson (1), Nelson (2), Chardon (3), and Copley (4). Letters indicate approximate locations of specimens with chemcal analyses shown in Table 1.

In an alluvial plain or delta deposit, deposition is more variable near the outer limit than near the source. If the Sharon sheet represents either type of deposit, the more abundant orthoquartzite lenses in the south would suggest a northern source for the Sharon.

\section{PLATE 1.-SEDIMENTARY FEATURES OF THE SHARON CONGLOMERATE}

Figure 1.-Orthoquartzite Lens in Conglomerate Phase of Sharon Conglomerate Lens lies at an angle to the principal bedding

Figure 2.-Channel Cut in Orthoguartzite Phase of the Sharon and Fruled with Conglomerate Phase

Figure 3.-Ciay Masses in the Conglomerate Phase of the Sharon

Large clay mass above the hammer shows no contortion and little rounding of the end; clay mass at hammer point was contorted and rounded during movement.

Figere 4.-Sharon Conglomerate Showtng lag Gravels

Bed below hammer with faint cross-bedding is typical of orthoquartzite with scattered pebbles; below this bed and above the hammer are beds of lag gravels. 
Some orthoquartzite-conglomerate contacts are sharp, where the conglomerate shows a definite channel relationship to orthoquartzite or orthoquartzite with scattered pebbles (PI. 1, fig. 2). Other contacts are gradational, with the conglomerate gradually changing into a pebbly orthoquartzite and sometimes into a pebblefree orthoquartzite. These lateral variations suggest scour channels, the definite contacts being on the undercut side of the stream and the gradational contacts on the slipoff slopes.

Shale lenses and clay masses are associated with the conglomerate belts. Shale and clay are blue gray in color and weather light gray; both are slightly sandy. Lenses of shale a few inches to several feet thick are visible for several hundred feet in some outcrops. Clay masses are either angular pieces, which show little evidence of movement except their random orientation in the deposit, or rounded masses with contorted bedding, obviously molded during transportation (Pl. 1, fig. 3). These masses range from pieces a fraction of an inch in diameter to lenticular bodies 6 feet long and 1 foot thick.

The lenses appear to be quiet water deposits formed away from the main currents. When the main current would shift back into the area, it would either cover the fine clastics with sand and pebbles forming a shale lens or sweep up blocks of clay some of which were moved intact and others contorted and rounded during transportation.

\section{Conglomerate Beds}

Several horizontal beds of well-sorted conglomerate are usually seen in large exposures of orthoquartzite or conglomerate. When present in orthoquartzite these beds are very distinctive and can be followed across the whole outcrop although they may be only one pebble thick or several feet thick. Even in an outcrop which is dominantly conglomerate, these beds are distinctive because their pebbles are so well sorted while those of adjacent beds are more poorly sorted (Pl. 1, fig. 4). Flattened pebbles in these beds are often found imbricated with an alignment indicating a northern source.

Gradient apparently was such that the characteristic deposit was a mixture ranging from fine sand to coarse gravel. Probably the sand moved by saltation and in suspension while the pebbles rolled along the bottom. If the current increased and caused erosion of this newly deposited sand and gravel mixture, the sand would be swept free and the pebbles concentrated slightly lower in a layer. These wellsorted, horizontal, conglomerate beds, therefore, are called lag gravels.

\section{Cross-Stratification}

Both orthoquartzite and conglomerate show abundant cross-stratification. In describing this feature the writer has followed the purely descriptive classification of McKee and Weir (1953, p. 381-390), even though he does not agree completely with them. The strata of the cross-beds dip south and one planar cross-set is piled on top of another with occasional intervening strata with horizontal bedding.

Each stratum is normally between one half and two inches thick though thicker strata have been observed. According to McKee (1953, p. 383) the rock would be classified as very thinly cross-bedded. In the grits and conglomerates the cross-bedding stands out be-

\section{Plate 2.-CHARACTERISTICS OF THE SHARON CONGLOMERATE}

Figure 1.-Cross-beds with Overturned Tops

The upper bed shows cross-bedding whose top has been overturned due to creep on the original depositional slope. Right is south.

Figure 2.-Graded Cross-bedding

Phalanx quarry of Industrial Silica Corp.

Figure 3.-Initial Depositional Slope to the South

Bedding planes separating cross-bedded conglomerate layers show initial depositional slope to south (left) which has been slightly accentuated by later orogenic movement.

Figure 4.-Common Occurrence of Conglomerate Near Base of Sharon

with the Sandstone Phase Over It

Mississippian-Pennsylvanian contact just below the quarry base 
cause the textures of the successive strata differ. Texture variation probably also accounts for the cross-bedding in the mediumgrained orthoquartzites although this cannot be determined by the naked eye. The crossbeds may be a set of parallel foreset beds with no top or bottomsets but more characteristically they are a set of foresets grading imperceptibly in to bottomsets, the whole with a slight upward concavity. No topset beds have been observed but some of the horizontal layers probably represent reworked ones; if the reworking continues long enough a well-sorted pebble layer results which has been described as a lag gravel.

In weathered sections the cross-bedding planes may serve as bounding surfaces and flaggy blocks may develop. Where a stream cuts across the dip of these blocks a confusing series of false bedding planes results. The crossstrata are of medium scale with an average length of several feet, but some are large scale$20-45$ feet long.

A set of cross-strata is tabular and may be followed for several hundred feet along a quarry face or outcrop with little change in thickness. Eventually it thins and disappears owing to erosion and is replaced by another set of crossstrata or by horizontal layers. The thickness of the set is normally 1 foot to $11 / 2$ feet and the range is 6 inches to 6 feet.

Locally, erosion has cut troughs through the planar cross-bedding and the deposits in these troughs are themselves cross-bedded. Except for the curved erosion surface at the base, this cross-bedding is similar in every way to the planar cross-bedding, and would be classified by $\mathrm{McKee}$ and Weir as trough cross-bedding. It is more prevalent in the southwestern part of the area, indicating that conditions changed more rapidly in the south, and further supporting the concept of a northern source.

Another feature of some cross-bedded areas is the overturning of the top of the cross-beds, which gives the cross-beds the appearance of being folded (PI. 2, fig. 1). This apparent folding is not an orogenic feature because it lies between undisturbed horizontal layers. It is obviously caused by creep of the cross-bedded sand down the depositional slope before consolidation and before deposition of the over- lying beds. All observed overturnings are southerly in direction.

Several hundred measurements were taken of the strike and dip of the cross-beds. In the Sharon the dip directions range from east through south to west. The dip varies from $7^{\circ}$ to $26^{\circ} \mathrm{S}$. with the greatest number $20^{\circ} \pm$ a few degrees. In a single outcrop several dip directions for the cross-beds might be observed, but they clustered around a general trendfor example, all dip directions might be in the southeastquadrant. Lack of northeastand northwest dipping cross-beds indicates that the flowing water from which these cross-beds were deposited must have had a northern source.

In one locality in the southeastern part of the outcrop area (Industrial Silica Corp. Phalanx quarry) graded cross-bedding is observed in some strata (Pl. 2, fig. 2). This phenomenon is due to deposition of cross-beds in quiet water. More rapid settling of the coarser material caused the development of graded bedding in individual cross-strata.

\section{Initial Slopes}

In most large outcrops of the Sharon the tops of the cross-bedded layers and the associated relatively horizontal beds dip about $3^{\circ} \mathrm{S}$. or about 275 feet per mile (Pl. 2, fig. 3). On the basis of a study of the Berea of the eastern part of this region, De Witt (1946) drew structure contours on top of the Berea which indicate an average southerly dip of 11 feet per mile. The difference between the amount of regional dip and the dip observed in the beds of Sharon indicates that the Sharon built forward with a marked initial slope. The initial slope varies in direction from southeast to southwest normally, but in one locality, the east side of the number 1 quarry of the Industrial Silica Corp. at Phalanx, there is a $\operatorname{dip} 4^{\circ} \mathrm{E}$. 'This seems to be a depositional slope where the deposits were building up against a Mississippian shale hill.

\section{Composition}

The high silica content of the Sharon orthoquartzite and conglomerate has been mentioned. Bowen (1953, p. 41-43) published the 
first modern analyses of the Sharon. He cut clean channel samples from the whole exposed cliff face of the quarries in the northern part of Area B. The samples represent the total
Elimination of these two samples leaves eight certain Sharon analyses, six of which are conglomerates and two orthoquartzites. (See Table 1.) The last two columns of Table 1 give the

Table 1.-Analyses of Sharon Samples Arranged from North to Solth to Show Systematic Change

\begin{tabular}{|c|c|c|c|c|c|c|c|c|c|c|}
\hline & \multicolumn{6}{|c|}{ Conglomerates } & \multicolumn{2}{|c|}{ Orthoquartzites } & \multirow{2}{*}{$\begin{array}{c}\text { Average of } \\
\text { Conglom- } \\
\text { erates }\end{array}$} & \multirow{2}{*}{$\begin{array}{c}\text { Average of } \\
\text { Ortho- } \\
\text { quartzites }\end{array}$} \\
\hline & A & $B$ & $\mathrm{C}$ & $\mathrm{D}$ & $\mathrm{E}$ & F & G & $\mathrm{H}$ & & \\
\hline $\mathrm{SiO}_{2}$ & 98.95 & 98.80 & 98.13 & 98.82 & 97.87 & 97.81 & 97.91 & 96.62 & 98.38 & 97.27 \\
\hline $\mathrm{R}_{2} \mathrm{O}_{3}{ }^{*}$ group & 0.74 & 0.92 & 1.15 & 0.72 & 1.45 & 1.44 & 1.59 & 2.23 & 1.07 & 1.91 \\
\hline $\mathrm{Al}_{2} \mathrm{O}_{3} \ldots \ldots \ldots$ & 0.52 & 0.63 & 0.85 & 0.38 & 0.88 & $0.92 \dagger$ & 1.24 & 1.72 & 0.71 & 1.48 \\
\hline $\mathrm{Fe}_{2} \mathrm{O}_{3}$. & 0.17 & 0.24 & 0.24 & 0.31 & 0.50 & 0.45 & 0.29 & 0.38 & 0.32 & 0.34 \\
\hline $\mathrm{TiO}_{2}$ & 0.04 & 0.03 & 0.05 & 0.02 & 0.06 & 0.05 & 0.05 & 0.12 & 0.04 & 0.09 \\
\hline $\mathrm{MnO}$. & 0.01 & 0.01 & 0.02 & 0.01 & 0.01 & 0.01 & 0.01 & 0.01 & 0.01 & 0.01 \\
\hline $\mathrm{CaO}$. & 0.00 & 0.00 & 0.18 & 0.00 & 0.06 & 0.11 & 0.04 & 0.00 & 0.06 & 0.02 \\
\hline $\mathrm{MgO}$. & 0.02 & 0.02 & 0.01 & 0.01 & 0.03 & 0.01 & 0.03 & 0.08 & 0.02 & 0.06 \\
\hline $\mathrm{K}_{2} \mathrm{O}$ & 0.04 & 0.05 & 0.05 & 0.04 & 0.08 & 0.03 & 0.09 & 0.24 & 0.05 & 0.17 \\
\hline $\mathrm{Na}_{2} \mathrm{O}$ & 0.01 & $\operatorname{Tr}$ & 0.00 & 0.00 & 0.01 & 0.00 & 0.01 & 0.00 & 0.01 & 0.01 \\
\hline $\mathrm{SO}_{3} \ldots$ & 0.01 & 0.01 & 0.06 & 0.00 & 0.00 & 0.05 & 0.00 & 0.00 & 0.02 & 0.00 \\
\hline
\end{tabular}

* $\mathrm{R}_{2} \mathrm{O}_{3}$ group contains $\mathrm{Al}_{2} \mathrm{O}_{3}, \mathrm{Fe}_{2} \mathrm{O}_{3}, \mathrm{FeO}, \mathrm{FeS}_{2}, \mathrm{TiO}_{2}, \mathrm{MnO}, \mathrm{V}_{2} \mathrm{O}_{5}, \mathrm{P}_{2} \mathrm{O}_{5}$ and $\mathrm{ZrO}_{2}$.

† By mistake given as 0.97 in Table II of Bowen (personal communication).

A-R. W. Sidley Inc. Thompson Quarry.

B-R. W. Sidley Inc. South Thompson Quarry.

C-Walter C. Best Inc.

D-Harbison-Walker Refractories Co., Nelson Ledges.

E-Industrial Silica Corp. Phalanx Plant.

F--Industrial Silica Corp. Phalanx Plant.

G-Industrial Silica Corp. Phalanx Plant.

H-Industrial Silica Corp. Sandy Flats Quarry.

thickness of the formation in these localities lacking only a few feet which have been removed by erosion or left in the quarry bottom for a floor. Because the depth of the sample taken was about one inch in sandy material and equal to the diameter of the largest pebble in conglomeratic material the total sample ranged in weight between 10 and 50 pounds. In a formation which varies rapidly in texture both horizontally and vertically these clean samples cutting across practically the whole formation give a better concept of the composition than was available from the grab samples used in older analyses.

Bowen (1953, p. 41-43) included in his Table II analyses of two samples which were shown by Pedry (1951, thesis Ohio State University, p. 57-58) to be Massillon instead of Sharon. averages of the conglomerates and orthoquartzites respectively. Both averages indicate that Sharon $\mathrm{SiO}_{2}$ content is in the high nineties and that the only impurities of importance are $\mathrm{Al}_{2} \mathrm{O}_{3}$ and $\mathrm{Fe}_{2} \mathrm{O}_{3}$. The next most abundant impurity is $\mathrm{TiO}_{2}$ which averages 0.07 in the eight samples. 'This average is not very representative because only one sample has over $0.07 \mathrm{TiO}_{2}$. All other impurities are insignificant.

Comparison of the average analyses of conglomerates and orthoquartzites confirms two field observations regarding purity: that the conglomerates are slightly purer than the orthoquartzites and that this difference is mainly due to a higher clay content in the fines.

Bowen's analyses of the plus-four-mesh compared with the minus-four-mesh of the same sample confirms the idea that impurities 
are more abundant in the finer material. $\mathrm{He}$ states,

"The plus-four-mesh grade varied between 98.92 per cent and 99.59 per cent silica, the minus-fourmesh grade from 96.62 per cent to 98.69 per cent silica. The chief contaminating ingredient was alumina which varied between 0.06 and 0.34 per cent in the coarse fraction and from 0.66 to 1.72 in the fine." (Bowen, 1953, p. 39.)

In Table 1 the eight Sharon analyses are arranged in order from north to south. Position of the localities is shown on Figure 1. Samples $\mathrm{E}, \mathrm{F}$ and $\mathrm{G}$ are from different parts of the Industrial Silica Corporation's quarry at Phalanx and were taken roughly east-west across a conglomerate belt. Sample E is conglomerate with very little sand matrix; Sample $F$ is conglomerate with a fair percentage of sand matrix, and Sample $\mathrm{C}$ is an orthoquartzite with a few scattered pebbles. Variations in chemical composition between these three specimens are probably due to increased fineness of particles and consequent increase in impurity. Although $E$ is actually north of $F$ and $F$ north of $G$ they should be treated as one locality when considering the north-south variation in composition. The significant horizontal lines in the table are the first four. The $\mathrm{SiO}_{2}$ content decreases progressively from north to south while the impurities represented by the other three columns gradually increase. The progression is not perfect but it seems significant. The number of samples considered is so small that this change in composition from north to south is not sufficient in itself to prove a northern source for the Sharon conglomerate but it does advance confirmation.

Bownocker (1921; 1926) published the only other analyses of the Sharon. Several samples he called Sharon are now known to be Massillon and the location of others is so indefinite that they may be either Massillon or Sharon. All his samples were chip samples and some were iron-stained. Yet six certain Sharon samples (1921, p. 256 ; 1926, p. 39-40) are from locations in the southwestern part of the area where Bowen did not work; their average composition is: $\mathrm{SiO}_{2}$ 98.17; $\mathrm{Al}_{2} \mathrm{O}_{3} 0.43 ; \mathrm{Fe}_{3} \mathrm{O}_{4} 0.39 ; \mathrm{CaO} 0.03$; $\mathrm{MgO} 0.06 ; \mathrm{TiO}_{2} 0.05$; loss on ignition 0.32 . This substantiates the field observation that the Sharon throughout Area B is a pure orthoquartzite or conglomerate.

\section{Mechanical Analyses}

Bowen mechanically analyzed his samples from the northeastern part of Area B. He reached several conclusions which are in accord with the ideas previously presented by the writer (Fuller 1947; 1950a; 1950b) and expanded in this paper.

Plotting by Bowen (1952, dissertation, Ohio State University, p. 60-61) of median grain diameter against logarithmic sorting coefficient indicates better sorting in samples with smaller median diameter than in the coarser samples. This agrees with the conclusion reached by Inman (1949, p. 67) for sediments transported by currents of water and supports the writer's idea that the Sharon is a water-laid deposit. Best sorting lies between 0.15 and $0.30 \mathrm{~mm}$., which is higher than the $0.125-0.250 \mathrm{~mm}$. stated by Inman as characteristic of well-sorted sediments. Bowen feels that this slight upward shift in size is probably related to post-depositional enlargement of the grains by silica and that the Sharon is a very well-sorted deposit with the characteristics of such deposits.

Cumulative curve plots of the median grain size against the sorting coefficient in the mechanical analysis of successive beds at a particular locality along a conglomerate belt produce a bundle of curves. The medians of these bundles show a progressive spread southward. The close spacing of the medians at the north "suggest that the competency of the currents in this part of the region tended to remain rather constant over a considerable period of time. The progressive widening of the curve bundles toward the south... indicates a marked fluctuation in competency at these sites." (Bowen, 1952, dissertation, Ohio State University, p. 62). The main current would be expected to meander more in the lower part of a delta or alluvial fan than in the upper part and this would account for fluctuation in competency at any one locality. Similarly, competency would fluctuate if the main current were subject to the braking power of a body of quiet water.

Bowen (1953, p. 11) reports that

"the percentage of pebble (plus-four-mesh) in the conglomerate showed a progressive decrease southward varying from 35 to 54 per cent pebble in the north to between 25 and 32 per cent in the south." 
"A corresponding increase in sorting is noted as these belts are traced southward. These variations are quite similar to those noted in modern streams and indicate a movement of material from north to south." (Bowen, 1953, p. 47.)

In contrast to this gradual increase in sorting power along the channel axis, study of curves of samples taken across the axis in the Phalanx quarries of the Industrial Silica Corporation indicates a rapid increase in sorting with an equally rapid decrease in grain size. Bowen (1952, dissertation, Ohio State University, p. 68) notes that

"Russell (1939) has pointed out that progressive sorting according to size would be rapid where currents were carrying debris through a body of quiet water and with a rapid decrease in velocity. Hence, this rapid later increase in sorting suggests that the material away from the pebble channels was deposited in quiet water."

Bowen's works on mechanical analyses of the Sharon in the northeastern part of the area supports the idea of a northern source for the water-laid deposits of the Sharon. It also suggests that the progressive rapid sorting going outward from a channel center in the Phalanx region indicates deposition in a body of quiet water. As this is the same quarry in which graded cross-bedding is found, it seems that in this part of the region the Sharon sediments were deposited in a body of quiet water. These facts suggest deltaic plain environment rather than an alluvial fan.

\section{Pebbles}

In the early literature not much attention was paid to the character and significance of the pebbles in the Sharon conglomerate. They were usually identified as quartz, with occasional jasper pebbles. J. S. Newberry (1873, p. 213-214) published the most complete description of the pebbles and their origin, and the description is such a revelation of the thinking of the time that it is worth quoting in part:

"The pebbles of the more pebbly portions of the Conglomerate are sometimes as large as one's fist, but more generally range from the size of a hickory nut to that of an egg. They are almost always composed of quartz, but in every locality where they are abundant, more or less of them may be found which are composed of quartzite or silicious slate, which show lines of stratification.... There can be no question, however, that these pebbles are portions of quartz veins, which have been brought hundreds of miles from some area where metamorphic, crystal- line rocks have suffered erosion. In the process of transportation the attrition to which these fragments were subjected comminuted all but the most resistant, viz: the quartz. The banded, silicious slates which are represented in the pebbles that accompany those of pure quartz, as well as the internal structure of the quartz pebbles themselves, afford conclusive evidence that their origin is such as I have described. ... I have for many years been inclined to refer to transportation and deposition of the immense beds of quartz pebbles which are found in the Conglomerate to the same cause which has transported the gravels of the Drift, and the similar deposits which are now accumulating on the sea bottom off the Antarctic Continent, and on the Banks of New Foundland-viz: to ice."

Newberry's idea of ice transportation and deposition was soon dismissed by geologists when they learned more about the character of drift. His concept that "these pebbles are portions of quartz veins" was readily accepted and retained. Overlooking his reference to pebbles of metamorphic origin, later geologists spoke of the pebbles of the Sharon as being "vein quartz" derived from erosion of an "igneous source rock". Stout (1916, p. 441), in discussing the Sharon conglomerate of southern Ohio, considered the Sharon of northeastern Ohio and southern Ohio to have the same northern source. He says the Sharon "is largely crystallized quartz, and thus of igneous origin derived from the granitic rocks". Stout realizes the difficulty of obtaining all this quartz from erosion of a crystalline series but still holds to that concept (1916, p. 441). His (1916, p. 443) solution to the difficult problem involved in producing this amount of pure quartz is summarized as follows:

"Considering all points, the history of the Sharon conglomerate seems to indicate that the decay of the crystalline rocks reached an advanced state on low lying uplands; that the products were slowly transported to the sea, coarse materials lagging far behind the finer products; that the fine materials were distributed to the deep and quiet waters, forming shale, while the coarse materials were left more localized along the margins; that a general elevation took place, converting much of the floor of the sea to land, and restricting the currents to narrow shallow passages; that the force of these currents was now sufficiently strong to transport the coarse quartz, and thus build up the conglomerate."

Although Stout's explanation is a possibility, the following facts argue against it being the correct theory of origin:

1. Lack of any crystalline remnants, rocks or minerals except quartz 
2. Well-rounded quartz grains and pebbles

3. Lack of extensive shale deposits representthe fines deposited in deep water

In searching for the solution a detailed study of the quartz pebbles was started.

Over 90 per cent of the pebbles are a clear to milky quartz called "vein quartz" in the literature. The remaining pebbles described in the literature are smoky quartz, jasper, "silicious slates" and quartzites. 'The writer has found pebbles of sandstone, conglomerate, leached rotten limestone which has been silicified and several different orthoquartzites ranging from black to white. Most instructive of all was the discovery of quartzite conglomerates with pebbles just like those of the Sharon and the discovery of fossils as pebbles.

Most of the quartz pebbles, like the sand grains, show secondary enlargement by silica. These enlarged pebbles have a distinctive luster which is due to reflection of light from the many tiny crystal faces developed on the original curved surface.

Bowen (1953, p. 21) made an odd pebble collection at each locality he visited and states that the odd pebble suites "were purely qualitative in nature; however, they did indicate a progressive decrease in the more fragile types, sandstone, grainy quartzite, etc., from north to south." More resistant odd types like chert, jasper and well-cemented quartzite also decreased to the south but to a less marked degree. The north-south decrease in odd pebbles indicates longer transportation for the southern material and supports the contention of a northern source for the Sharon.

The pebbles of conglomerate are interesting because the sand matrix is just like the sand of the Sharon and the pebbles are the same as the white or milky quartz pebbles of the conglomerate phase of the Sharon. Even in a thin section no distinction could be made. Here then is a sedimentary remnant of an older formation which undoubtedly supplied some of the sand and pebble for the Sharon. Some of these pebbles are cut by tiny quart $z$ veins, indicating intrusion of quartz into the sediments. Such veins may be the source of some milky quartz.

Bowen (1953, p. 10) discovered a glacial erratic resembling a Sharon boulder. Close examination indicated that it is different from true
Sharon erratics. It is a coarse quartzite conglomerate, the quartz grains of the matrix are larger than the average grain size of the Sharon conglomerate and they are cemented with silica. Although Sharon conglomerate is sometimes well cemented by limonite, no siliceous cement has been found. The pebbles of the quartzite are the same as the more durable ones found in the Sharon, and in size are similar to the Sharon conglomerate pebbles although they are less well rounded and sorted and there is no cross-bedding. This boulder represents a formation exposed in Pleistocene time, and it is not unreasonable to believe that during Pennsylvanian time this formation may have been eroded to supply some of the materials for the Sharon.

\section{Fossils}

Fossils have been found only in the thicker conglomerate zones, but they have been discovered in five localities, the farthest separated being 40 miles apart. This suggests that the fossils are fairly widespread, and, now that the technique of locating them has been learned, examination of all conglomerate channels should turn up a few fossils.

In 1947 the best specimens of the first discovery were turned over to Dr. John W. Wells for identification. He reported:

"About 20 specimens of fossils, occurring as fragments in the Sharon conglomerate ... have been examined... all are in poor condition mostly as a result of leaching and some silicification. All are incomplete and more or less worn, most of them [are] rugose or tabulate corals, but one or two fragments evidently were small bits of fossiliferous limestone and show small bits of trilobites, brachiopods, and Tentaculites. Unfortunately the trilobites and brachiopods are mostly quite indeterminable, and the only satisfactory identifications are for the corals and Tenlaculiles. List of specimens: CoralsFavosites sp. cf. F. hemispherica (Troost), Favosites sp. cf. F. placenta Rominger, Emmonsia emmonsi (M. E. \& H.), Emmonsia sp., Prismatophyllum sp., Synaptophyllum sp. cf. $S$. simcoense (Billings); Brachiopod-Ambocoelia umbonata (Conrad)?; Gastropod-Tentaculites bellulus Hall. In addition to the above there are two specimens representing two additional genera of solitary rugose corals. The above material is all characteristically Middle Devonian (Onondaga-Hamilton). Extensive outcrops of strata of this age certainly existed during early Pottsville time to the east, north, and west, of the site of Sharon deposition, and the remanie specimens could have come from any or all of these. The matrix and fossils themselves, however, are too 
altered to suggest a narrowing down of these sources on a lithologic basis."

\section{Vein Quartz}

Odd pebbles such as sandstones, conglomerates and fossils which were derived from sedimentary material establish the Sharon as partially of sedimentary source. However, the great bulk of the pebbles are milky or vitreous quartz and have been called "vein quartz", suggesting an igneous source. It should be noted that no pebbles of igneous rocks, of schist, or gneiss have been found. "Silicious slate" was reported by Newberry alone but he was probably referring to the dark-banded quartzite pebbles. Furthermore, the purity and secondary enlargement of quartz grains and pebbles indicate a deposit of at least a second generation. It seems logical, therefore, to think that a large percentage of these so called "vein quartz" pebbles might also be derived from a sedimentary source or from a pure metaquartzite.

It has already been pointed out that the conglomerate formation which supplied the conglomerate pebbles must have supplied some sand and pebble as well, and that some of the clear or milky quartz pebbles may have come from the source formation of the quartzite conglomerate erratic discovered by Bowen. That a pure metaquartzite was also a partial source must be considered.

Bowen examined about 20 thin sections of these pebbles and reported no positive grains of quartz. He states: "The so-called white massive pebbles appear to be vein or igneous quartz. All show large crystal size with a well developed lattice orientation. Many of the large crystals are in turn divided into smaller, subsidiary blocks or a mosaic pattern which the author regards as being due to strain." (Bowen, 1952 , p. 92). While retaining the idea that the original source was igneous, Bowen admits that the purity of the whole formation signifies more than one cycle of deposition.

However, even if several cycles of erosion are accepted to justify the purity, the fact of an igneous origin is still not substantiated since not a single igneous pebble, no typical vein quartz accessories, and no variety to the heavy minerals are to be found. Erosion of a pure metaquartzite would be a more logical source for the Sharon quartz pebbles. An orthoquartzite could be metamorphosed so that almost all evidence of the former sedimentary character would be destroyed.

C. A. Lamey (1935) studied the Palmer gneiss which was previously considered part of the Archean Basement Complex cut by Laurentian granite. He found that it really consisted of a variety of Huronian sediments including quartzites of the Mesnard formation. The sericitic and ferruginous varieties of the quartzites usually show their clastic origin.

Lamey states (1935, p. 1154):

"The vitreous varieties, however, do not always so clearly show their clastic nature. This is usually revealed by a careful examination under a hand lens, and also by a microscopic inspection. Without the use of the analyzer the outlines of rounded quartz may be seen, especially if they are fringed with a small amount of iron oxide, but under crossed nicols these outlines, although observable, are not very apparent, due to the deposition of siliceous cement with the same optical orientation as the original quartz grains and in some instances there is little indication of original grains."

Pebbles derived from erosion of the vitreous quartzite described by Lamey could easily be mistaken for vein quartz.

Another example of vitreous quartz which is not igneous is the Sturgeon quartzite of the Felch Mountain range. Smyth, in a monograph by Clements and Smyth (1899, p. 400), describes the Sturgeon quartzite as a light-gray rock which breaks with a coarsely granular or glassy fracture. Quartz is often the only visibly recognizable constituent. The formation is so homogeneous that it is difficult to determine structure alone but field relations establish it as a sedimentary rock, well exposed in the Felch Mountain range in two parallel belts. Recrystallization has almost obliterated the sedimentary features and "Faint color banding, itself of secondary development, but no doubt preserving a distinction in original composition, alone remains, and only here and there, as a guide to the former stratification."

Smyth (in Clements and Smyth 1899, p. 402) describes a gradational series in thin sections from those consisting of large irregular grains of quartz with interlocking boundaries and inclusions of accessory minerals, through optically strained and elongated quartz, through fractured quartz with intergranular movement 
producing a fine-grained quartz mosaic between the parted surfaces, and ending with highly strained quartz in long narrow lenses separated by anastomosing zones of finely divided quartz. All these were observed in individual pebbles of the Sharon. Erosion of a pure zone of quartzite similar to the Sturgeon quartzite could produce pebbles similar to the socalled "vein quartz" of the Sharon.

Since pure orthoquartzite can be metamorphosed so much that definite grain boundaries may be destroyed, causing it to resemble vitreous or vein quartz, the igneous quartz must be distinguished from metamorphic quartz on other criteria than definite dust rims or secondary quartz rims. Re-examination of Bowen's thin sections confirmed the lack of dust rims and clear boundaries of quartz grains. The slides show three types of granular pattern. A few show in plain light incipient fractures from stress which has broken crystals in small equigranular, angular blocks. Under crossed nicols all slides also show a granular pattern which represents the crystallographic units. All crystals have strain extinction. Their boundaries are interlocking in varying degrees of complexity and in a few specimens the boundaries are a mylonite between larger crystals. The third granular pattern is the most difficult to see but it is the most significant. In plain light, inclusions are found in all crystals in varying quantity. Where concentrated they are aligned to surround oval areas. In the lines where inclusions are most abundant there is also a greater variety of inclusions, some of which are crystals. Most are irregularly shaped gas or liquid inclusions with an index of refraction below quartz. The long axis of many irregular inclusions is on a tangent to the oval area of quartz. On the other hand, this type of inclusion within the oval mass is unoriented. In polarized light a single crystal is seen to span several of these rounded areas. Some are round while others appear elongated and angular. In a single pebble they are quite uniform in size and shape.

These oval areas are believed to represent original sand grains and the aligned inclusions are believed to be equivalent to the dust rims commonly observed when a metaquartzite has been produced. Because of high purity of the original sand and extreme recrystallization, grain boundaries and good dust rims are absent but the ghost grains are still visible. Some of these grains may have been flattened during the metamorphic process but the general granular structure persisted during recrystallization and the gas, liquid and minor accessories which originally occupied the pore spaces are believed to have been trapped in their approximate positions as the quartz recrystallized. The newly formed crystals include several of the original grains and grain boundaries. Within the original grain the inclusions are unoriented, but pressure is believed to have concentrated and aligned the inclusions of the voids around the original grain.

Of the 14 slides of quartz pebbles, 12 show definite ghost grains. In the majority of these slides the ghost grains will be well-developed in some areas and less certain in others. The quartz of the remaining two slides shows a fracture mosaic which masks the ghost structure and makes its presence uncertain. Because most of the pebbles show these ghost grains their source is believed to be a metaquartzite rather than vein quartz.

A further check to distinguish metamorphic from igneous quartz was made using the type of inclusions demonstrated by Mackie (1896, p. 154). According to Mackie's law, under a magnification of 100 times or more, quartz with acicular inclusions is derived from an igneous rock and quartz with regular or crystal inclusions is derived from a metamorphic source. Irregular inclusions are common to quartz of either source and, therefore, are not definitive. Other workers (Gilligan, 1920; Tyler, 1936) have used Mackie's discovery, apparently with success, to determine the source rock for sediments. The closest use of Mackie's law to the Sharon geographically is the work of Tyler (1936) in the St. Peter sandstone of Wisconsin.

Bowen's thin sections of quartz pebbles were examined for types of inclusions. No acicular inclusions are found but all specimens have regular crystal inclusions and abundant irregularly shaped gas and liquid inclusions. If Mackie's law is valid the quartz of these pebbles was derived from metamorphic rocks. 
The very high percentage of quartz in the Sharon suggests that the original source rock for the pebbles must have been either a pure metaquartzite or a quartz-rich metamorphic rock which has been subjected to several cycles of erosion with the elimination of most of the impurities.

Inclusions in quartz of the orthoquartzite are similar to those in the pebble except that a few grains have acicular inclusions. Under Mackie's law the sand grains of the orthoquartzite also would be considered of metamorphic origin with a small percentage of igneous origin.

Study of inclusions in both pebbles and sand grains of the Sharon conglomerate was only exploratory. It is hoped that a more detailed study can be undertaken which will attempt to trace the material back to source rocks in Canada and/or older clastic rocks in Ohio on the basis of heavy minerals and similar inclusions in the quartz.

\section{Summary of Features Indicating a Northern Source}

The following features imply a northern source for the Sharon conglomerate of Area B:

(1) Southerly trending conglomerate belts whose merging pattern suggests distributary streams on a deltaic or aluvial plain

(2) Cross-bedding ranging in dip from southeast to southwest

(3) Creep of top of cross-beds to give overturning to the south

(4) Gentle southerly slope of the tops of cross-beds and horizontal beds which is markedly steeper than the regional dip.

(5) Pattern of imbricate structure locally where flattened pebbles are found

(6) More abundant lenses of orthoquartzite in conglomerate in the southern part of the area, indicating more rapid changing of sedimentation conditions

(7) More abundant trough cross-bedding in the southwest indicating more rapidly changing conditions here than nearer the source to the north.

(8) Progressive decrease southward in amount of pebble along a pebble belt from 35 to 54 per cent pebble in the north to 25 to 32 per cent in the south as shown by Bowen's mechanical analyses

(9) Elimination of fragile types of odd pebbles from north to south reported by Bowen

(10) Decrease in quantity of more resistent odd pebbles from north to south reported by Bowen

\section{Summary of Features Indicaling a Sedimenlary and Metamorphic Source}

The following features prove that the Sharon conglomerate is the result of erosion of a mixed sedimentary and metamorphic series and that an igneous source, suggested by the erroneous name "vein quartz" for the pebbles, is of minor importance.

(1) High purity $\left(96+\% \mathrm{SiO}_{2}\right)$ of the formation suggesting at least a second generation sand

(2) Both sand grains and pebbles with secondary quartz crystal faces which are characteristic of second generation sands

(3) Pebbles of sandstones, conglomerates, rotten limestones and silicified Middle Devonian fossils

(4) Several colors of quartzite pebbles with grain structure indicating at least several beds of quartzites

(5) Clear and milky quartz pebbles ("vein quartz") with ghost grain structure and regular inclusions characteristic of quartz recently derived from a metamorphic rather than an igneous terrain

(6) Most quartz grains with inclusions characteristic of quartz derived from a metaquartzite

(7) Rare quartz grains with acicular inclusions characteristic of recent igneous rock source

(8) Absence of igneous rocks, igneous rock minerals and a suite of heavy minerals typical of igneous rocks

\section{Character of Basin of Deposition}

Early ideas on the horizontal extent and vertical thickness of the Sharon conglomerate were colored by three different concepts which 
gave a false picture of the shape of the Sharon deposit and its basin of deposition. First, the extreme difficulty of separating Massillon sandstone (orthoquartzite) from the orthoquartzite phase of the Sharon when the intervening Sharon shale is absent, caused many

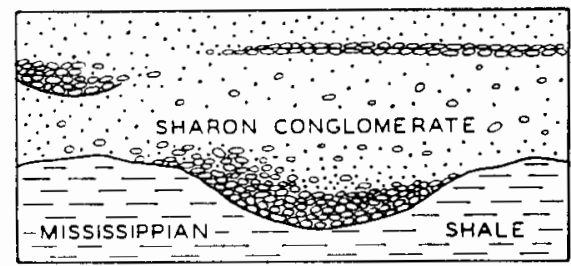

Figure 3.-Relationships of Conglomerate to Sandstone in the Sharon

thick sections of sandstone to be classed as Sharon (Newberry, 1878, p. 137-138) when actually both Sharon and Massillon are present. Second, experience in mining the Sharon coal indicated that the coal lay in a "series of troughs" (Roy, 1875; Orton, 1884, p. 227) 150900 feet wide trending in a southwest direction. The underlying Sharon conglomerate was also believed to be confined to troughs, and further, the conglomerate was believed to extend north of the coal basins still confined to troughs. Third, the lack of recognition of the fact that the Sharon is dominantly an orthoquartzite instead of a conglomerate and, therefore, that much of the orthoquartzite away from the conglomerate belts is Sharon rather than Massillon, supported the idea of a formation confined to long narrow depressions.

Detailed mapping of the Garrettsville quadrangle and parts of the quadrangles to the north and west has established the Sharon as a sheet-like deposit with a fairly flat top and an irregular base, caused by filling of the irregular topography of the Mississippian surface. In this sheet are belts of conglomerate with a southerly trend, which lie at any elevation but mainly in the lower part (Pl. 2, fig. 4), and which grade laterally into orthoquartzite (Fig. 3). This whole sheet, as shown by drill records and sections, thickens westward from the west edge of the Grand River Valley and formed in a large basin, the western extent of which is not known.

\section{Environment of Deposition}

Early ideas on the environment of deposition were diversified. As stated previously Newberry (1873, p. 213) considered the Sharon to be a glacial deposit dumped in a series of long narrow troughs; Stout (1916, p. 443), a sea current deposit restricted "to narrow passages"; and Lamb (1911, p. 105), a stream deposit.

Cross-bedding and high degree of sorting are so prominent in any large outcrop of Sharon that geologists today are certain that the Sharon is a water-laid deposit. The specific kind of water-laid environment is not as easily agreed upon. Some have suggested that the Sharon is a beach deposit. Thompson (1937) determined criteria for recognition of ancient bars, dunes and beaches from a study of modern beaches. Many features found in modern beaches are found in the Sharon on a larger scale. Most significant, however, are Thompson's conclusions (1937, p. 744) that ancient beaches are characteristically thin, generally less than 40 feet thick, that they rapidly lens and interstratify with marine or continental sediments, and that they are scarce in the geologic record. It seems certain that the extensive deposit of Sharon cannot be a beach deposit or even a transgressive beach deposit, although local areas may have some beach-deposited material.

At one locality a buried scarp has been found and deposits nearby suggest characteristics of upper foreshore beaches overlain by lower foreshore beaches (Thompson, 1937, p. 726740 ).

It has been suggested that the Sharon may be a series of offshore bars, bars, and spits. Characteristically these forms have complicated cross-stratification, while the crossstratification of the Sharon is consistent. These deposits, like beaches, are of such limited areal extent that the Sharon can not be considered to be dominantly a series of bars.

The third possible environment of deposition is an alluvial or deltaic plain. Deposition in this environment most readily explains these characteristics which have already been discussed: (1) widespread thick deposit with 
irregular base and relatively flat top, (2) radial distribution of the conglomerate belts, (3) long lateral extent of some conglomerate belts, (4) uniformly high degree of sorting in individual beds, (5) consistent widespread simple cross-stratification, (6) widespread initial slopes, and (7) lag gravels.

Further work may define the detailed extent and character of the alluvial or deltaic plain and its source. The present concept is that of a highland in Canada which was composed of a Pre-pennsylvanian sequence of well-cemented quartzites, sandstones, conglomerates and limestones as dominant types. As this highland was eroded and the material transported to the south, rounded quartz pebbles were formed from the quartzites and the pebbles of the conglomerate, and abundant sand was produced from the sandstone and the matrix of the conglomerate. Most of the limestone went into solution, but some remnants persisted especially where silicified; among this silicified material were the fossils.

This material moved southward on an appreciable slope and was deposited in a broad basin near sea level, forming an alluvial or deltaic plain on which the distributary channels shifted position frequently. As these channels shifted, the load built forward in prominent cross-beds and layer after layer of cross-bedded orthoquartzite was deposited. At times increased current eroded the tops of these cross-beds, and as the velocity decreased again, nearly horizontal beds were deposited, or sheet wash beyond the active channels spread a similar horizontal layer.

Normally the stream gradient was such that the sand was carried and the pebbles rolled along the bottom to give a mixture of sand with scattered pebbles. Local increase in velocity in a channel sorted out the sand, and the pebbles concentrated in the deeper part of the channel, where they later came to form the conglomerate belts. Increase of velocity on the main plain, away from the channel, also caused erosion, which moved the sand farther south and concentrated the gravel at a lower level in a horizontal layer to form the laggravel sheets.

\section{Comparison with Area A}

Mapping in Area A has proceeded far enough to give a fair concept of the Sharon, and since this information is supported by that in the literature (White, 1880), it is evident that the Sharon of Areas A and B are similar. This deposit is mainly orthoquartzite with one known southerly trending conglomerate belt. The formation is thinner and the pebbles are smaller than those of Area B, which suggests that this area was farther from the source or had smaller streams to distribute the material.

Area A is separated from Area B by the broad Grand River lowland cut in Mississippian formations. Considering that the Sharon thins toward the east in Area B, and that the SharonMississippian contact rises in this area, the writer (1950) believes that the present Grand River Valley represents a Mississippian highland which separated the basin of Area A from Area B.

That Area A is distinct from Area $B$ is confirmed by the heavy mineral studies of Rittenhouse (1946, p. 1195), who says that the easternmost Sharon (Area A) and the Olean had the same source which was different from that of most of the Sharon (Area B) of northeastern Ohio.

\section{Comparison with Area C}

The writer and two students have mapped three townships in Area C (Jessup, D. E., 1951, thesis, Ohio State University, 97 p.; Weiss, R. M., 1951, thesis, Ohio State University, 101 p.). This work and reconnaissance indicate that the Sharon in Area $\mathrm{C}$ is similar to that of A and B. Similarity lies in the presence of pure orthoquartzite with scattered pebbles and linear pebble belts, well-developed crossbedding, silicified tabulate corals, and a few pebbles derived from sedimentary rocks. The thickness of the Sharon in Area $C$ is similar to that in Area A; Stout (1916, p. 42) reports a maximum of 200 feet. One conglomerate channel trending in a northwest-southeast direction has been followed for 9 miles and another for 6 miles. Both the northwestsoutheast trend of the channels and the west 
to north dip direction of the cross-beds indicate a southeastern source for the Sharon of Area C. Rittenhouse (personal communication) feels, however, that Areas B and C had a common source on the basis of "(1) similarity in roundness in heavy minerals in both areas, (2) similarity in chromite concentration in both areas (the relatively high chromite content in the Sharon is unique to that formation), and (3) the presence of Devonian fossils in Area C." These similarities do indicate that the original sources for the two deposits must have been very similar but not necessarily that they were the same.

Work by many geologists (Morse, 1910; Stout, 1916, 1918; Conrey, 1921; Meyers, T. R., 1929, thesis, OhioState University, 85 p.; White, 1949; Merrill, W., 1950, dissertation, Ohio State University, 444 p.; Flint, 1951; Hall, J. F., 1951, dissertation, Ohio State University, 218 p.; and Lamborn, 1954) has helped to prove a Mississippian highland in central Ohio. In Perry, southwestern Muskingum, eastern Licking, and northern Hocking coun ties the existence of the highland is shown by widespread areas of the youngest Mississippian formation, the Maxville limestone. In these same counties the oldest Pennsylvanian, Sharon conglomerate, is found only in the lowest valleys, and higher Pennsylvanian beds commonly overlie the Mississippian. In Coshocton and Holmes counties the highland is indicated by the complete lack of Sharon conglomerate. North and south of this highland lie the basins in which the Sharon conglomerate of Areas B and C were deposited.

\section{Conclusion}

Study of the Sharon conglomerate of northeastern and southern Ohio has modified older concepts of the character and origin of the Sharon. The writer has previously reported on some of these discoveries (1947; 1950); this paper summarizes the newer ideas on character and origin of this economically important pure orthoquartzite and conglomerate $(96+$ per cent $\mathrm{SiO}_{2}$ ).

Mapping has established three distinct Sharon areas in which the formation lies in basins on the original rolling Pre-pennsylvanian surface. The base of the Sharon is, therefore, irregular but the top is fairly regular. Dip of cross-bedding throughout the formation indicates deposition from rapidly flowing streams whose source was to the north in northern Ohio and to the southeast in southern Ohio. These source locations are confirmed by conglomerate belts with a southerly trend in northern Ohio and a northwesterly trend in southern Ohio. The radial pattern of the conglomerate belts suggests deposition on a deltaic or alluvial plain. In Area B dip of initial slope, direction of over-turning of tops of cross-beds, imbricate structure, and north-south changes in mechanical analyses, chemical analyses, and other sedimentary features also indicate a northern source.

In all areas the conglomerate belts contain shale lenses and masses which are believed to be quiet water deposits formed away from the channels of the stream, and later covered or eroded and moved to become clay mass pebbles. Well-sorted thin conglomerate beds from one pebble to several feet thick are found in the orthoquartzite and conglomerate. They are believed to be reworked topset beds or older cross-beds and are called lag gravels.

Pebbles of sedimentary rocks and Middle Devonian fossils as pebbles indicate that the source rocks for the Sharon must have been in part sedimentary. In northeastern Ohio (A rea B) discovery of ghost grain structure and inclusions in the quartz characteristic of metamorphic quartz indicates that the socalled "vein quartz" pebbles were not derived from an igneous source but are metamorphic in origin. The writer, therefore, feels that the northern source for the detritus of the Sharon was a mixed sedimentary and metamorphic terrain instead of igneous as was formerly suggested.

\section{References Cited}

Bowen, C. H., 1953, Petrology and economic geology of the Sharon conglomerate in Geauga and Portage counties, Ohio: Ohio State Univ. Eng. Expt. Sta. Bull., no. 153, 58 p.

Bownocker, J. A., 1921, Steal molding sands in Ohio: Ohio Jour. Sci., v. 21 , no. 8 , p. 249 266.

_ 1926, Glass sands in Ohio: Ohio Jour. Sci., v. 26 , no. 1 , p. $25-41$. 
Conrey, G. W., 1921, Geology of Wayne County: Geol. Survey Ohio Bull. 24, 155 p.

Clements, J. M., and Smyth, H. I., 1899, The Crystal Falls iron-bearing district of Michigan: U. S. Geol. Survey Mon. 36, 512 p.

DeWitt, W. Jr., 1946, The stratigraphic relationship of the Berea, Corry, and Cussewago sandstones in northeastern Ohio and northwestern Pennsylvania: U. S. Geol. Survey Oil and Gas Inv., Prelim. chart 21.

Flint, N. K., 1951, The geology of Perry County, Ohio: Geol. Survey Ohio Bull. 48, 4th ser., $234 \mathrm{p}$.

Fuller, J. O., 1947, Sharon conglomerate, a source of high-silica raw material: Ohio State Univ. Eng. Sta. News, v. 19, no. 2, p. 48-55.

- 1950a, Northern Middle Devonian sedimentary source for the Sharon Conglomerate of northeastern Ohio (Abstract): Geol. Soc. America Bull., v. 61, p. 1463-1464.

— 1950b, New discoveries concerning the Sharon conglomerate in northeastern Ohio (Abstract): Geol. Soc. America Bull., v. 61, p. 1567.

Gilligan, Albert, 1919, The petrography of the Millstone grit in Yorkshire: Quart. Jour. Geol. Soc. London, v. 75, p. 251-294.

Inman, D. L., 1949, Sorting of sediments in the light of fluid mechanics: Jour. Sed. Petrology, v. 19 , p. 51-70.

Lamb, G. F., 1911, The Mississippian-Pennsylvanian unconformity and the Sharon conglomerate: Jour. Geology, v. 19, p. 104-109.

Lamborn, R. E., 1954, Geology of Coshocton County: Geol. Survey Ohio Bull. 53, 245 p.

Lamey, C. A., 1935, The Palmer gneiss: Geol. Soc. America Bull., v. 46, p. 1137-1162.

Mackie, William, 1896, The sands and sandstones of eastern Moray: Edinburgh Geol. Soc. Trans., v. 7, p. 148-172.

McKee, E. D., and Weir, G. H., 1953, Terminology for stratification and cross-stratification in sedimentary rocks: Geol. Soc. America Bull., v. 64 , p. $381-390$.

Morse, W. C., 1910, The Maxville limestone: Geol. Survey Ohio Bull. 13, 4th ser., 128 p.

Newberry, J. S., 1873, Report of the Geological Survey of Ohio: Geol. Survey Ohio, v. 1, pt. 1, $680 \mathrm{p}$.

1873, Report of Geological Survey of Ohio: Geol. Survey Ohio, v. 3, pt. 1, 958 p.

Orton, Edward, 1884, Report of the Geological Survey of Ohio: Geol. Survey Ohio, v. 5, Econ. Geology, 1124 p.

Rittenhouse, Gordon, 1946, Grain roundness-a valuable geologic tool: Am. Assoc. Petroleum Geologists Bull., v. 30, p. 1192-1197.

Roy, Andrew, 1875-76, The Mahoning Valley coal region: Am. Inst. Min. Engineers Trans., v. 4, p. 188-190.

Russell, R. D., 1939, Effects of transportation on sedimentary particles in Trask, P. D., et al., Recent marine sediments, a symposium: Am. Assoc. Petroleum Geologists, p. 32-47.

Stout, Wilber, 1916, Geology of southern Ohio: Geol. Survey Ohio Bull. 20, 4th ser., 723 p.

1918, Geology of Muskingum County: Geol. Survey Ohio Bull. 21, 4th ser., 351 p.

Thompson, W. O., 1937, Original structures of beaches, bars, and dunes: Geol. Soc. America Bull., v. 48 , p. $723-752$.

Tyler, S. A., 1936, Heavy minerals of the St. Peter sandstone in Wisconsin: Jour. Sed. Petrology, v. 6 , p. $55-84$.

White, G. W., 1949, Geology of Holmes County: Geol. Survey Ohio Bull. 47, 4th ser., 373 p.

White, I. C., 1880, The geology of Mercer County: 2nd Geol. Survey Pa., Rept. Progress 3Q., $233 \mathrm{p}$.

The Ohio State University, Columbus 10, OHIO

Manuscript Received by the Secretary of the SOCiety, June 29, 1954 